\title{
PENERAPAN MODEL PEMBELAJARAN INKUIRI TERBIMBING DENGAN MEDIA PEMBELAJARAN MOLYMOD UNTUK MENGURANGI MISKONSEPSI SISWA PADA SUB POKOK BAHASAN GEOMETRI MOLEKUL
}

\section{APPLICATION OF GUIDED INQUIRY LEARNING MODEL WITH LEARNING MEDIA MOLYMOD TO REDUCE STUDENT MISCONCEPTIONS ON SUB TOPICS MOLECULAR GEOMETRY}

\author{
Rinda Angghita Putri ${ }^{1}$, Mukhamad Nurhadi ${ }^{2 *}$, Abdul Majid ${ }^{1}$ \\ ${ }^{1}$ Program Studi Sarjana Pendidikan Kimia, Fakultas Keguruan dan Ilmu Pendidikan, Universitas Mulawarman, \\ Samarinda, Indonesia \\ ${ }^{2}$ Program Studi Pascasarjana Pendidikan Kimia, Fakultas Keguruan dan Ilmu Pendidikan, Universitas \\ Mulawarman, Samarinda, Indonesia \\ *Corresponding Author: nurhadi1969@yahoo.co.id
}

\begin{abstract}
ABSTRAK
Penelitian ini bertujuan untuk mengetahui penerapan model pembelajaran Inkuiri Terbimbing dengan media pembelajaran molymod dalam mengurangi miskonsepsi siswa pada pokok bahasan Geometri Molekul kelas X MIPA 7 SMA Negeri 1 Samarinda. Teknik pengambilan sampel adalah purposive sampling, dimana diambil kelas dengan kemampuan sedang berdasarkan dokumentasi nilai oleh guru pada bab sebelumnya. Sampel berjumlah 32 siswa metode penelitian yang digunakan adalah eksperimen semu (quasi eksperimen) dengan desain penelitian one group pretest-posttest design. Teknik pengumpulan data yang digunakan berupa tes diagnostik berupa soal pilihan ganda dengan lembar jawaban yang dilengkapi dengan kriteria serta certainty of response indeks (CRI), yang digunakan untuk mengetahui kelompok pemahaman siswa. Berdasarkan hasil data analisis, persentase kelompok siswa yang mengalami miskonsepsi dengan persentase tertinggi mencapai $75 \%$ pada tes diagnostik 1 dan persentase kelompok siswa yang mengalami miskonsepsi setelah dilakukan pembelajaran dengan treatment model pembelajaran Inkuiri Terbimbing dengan media pembelajaran molymod pada tes diagnostik 2 menjadi 31,25\%. Hal ini menunjukkan terjadi penurunan persentase kelompok siswa yang mengalami miskonsepsi. Penurunan miskonsepsi siswa terjadi dengan persentase terendah 25\% hingga mencapai persentase tertinggi yaitu 53,13\%. Berdasarkan hasil analisis data, dapat disimpulkan bahwa miskonsepsi siswa menurun dengan penerapan model pembelajaran Inkuiri Terbimbing dengan media pembelajaran molymod pada pokok bahasan Geometri Molekul.
\end{abstract}

Kata kunci : miskonsepsi, tes diagnostik, Certainty of Response Index (CRI)

\begin{abstract}
The aim of the study to know the application of Guided Inqurry learning with molymod to reduce misconception on the sub topics Molecular Geometry on students of X MIPA 7 SMAN 1 Samarinda academic year 2016/2017. The sampling technique is purposive sampling, which class with moderate abilities was taken based on the teacher's documentation for student result from the previous chapter. The samples are 32 students. The research method used was quasi experiment with one group pretest-postest design. Data collection techniques used in te form of diagnostic test with multiple choice questions and the answer sheet that are equipped with the Certainty of Response Index (CRI) (CRI) criteria, which are used to determine student's understanding group. Based on the resutlt of the data analysis, the highest percentage of students who have misconception on first diagnostic test are $75 \%$ and the lowest percentage of students who have misconception after they have received treatment learning with Guided Inquiry learning model with instructional media molymod on second diagnostic test is $31,25 \%$.
\end{abstract}


This data indicates a change in the percentage of students who have rnisconception. Student's misconception have been reduced on first and second diagnostic tests with the lowest percentage is $25 \%$ and the highest percentage is $53,13 \%$,. Based on the analysis of data, it can be conclude that the student's misconception has been reduced by the application of Guided Inquiry learning rnodel with molymod learning media on the sub topics of Molecular Geometry.

\section{Keywords: misconceptions, diagnostic tests, Certainty of Response Index (CRI)}

\section{PENDAHULUAN}

Kesulitan dalam memahami konsep-konsep pada materi kimia dapat menyebabkan terjadinya kesalahpahaman. Pemahaman salah yang terjadi secara konsisten dan berkala ini disebut dengan miskonsepsi. Miskonsepsi pada umumnya dapat terjadi jika proses pembelajaran hanya terpusat pada guru, sedangkan siswa berada di posisi pasif, dimana siswa memperoleh informasi terpusat hanya dari guru saja. Penelitian yang dilakukan oleh Redhana dan Kirna (2014) menemukan bahwa siswa salah satu SMA di Bali masih banyak mengalami miskonsepsi terhadap konsep struktur atom, sistem periodik dan ikatan kimia. Rerata miskonsepsi siswa terhadap konsep struktur atom di kelas X dan XI masing-masing adalah $68,1 \%$ dan $45,9 \%$.

Hasil ini tentu tidak menggembirakan karena setelah siswa diajar oleh guru ternyata miskonsepsinya masih sangat tinggi. Setiawan (2013) dalam penelitiannya yang berjudul 'Pengaruh Model Pembelajaran Inkuiri Terbimbing terhadap Ketuntasan Hasil Belajar Siswa di SMKN 3 Buduran Sidoarjo' menunjukkan bahwa hasil belajar siswa dengan model pembelajaran inkuiri lebih baik dibandingkan dengan hasil belajar siswa dengan model konvensional. Berdasarkan penelitian di atas, apabila suasana belajar diubah sedemikian rupa, artinya suasana belajar dirancang untuk meningkatkan keaktifan siswa dan berorientasi terhadap proses, nantinya akan tercipta suatu proses pembelajaran yang akan meminimalisir kesalahan konsep pada siswa. Suasana inovatif seperti ini dapat dikembangkan pada kegiatan pembelajaran dengan menggunakan model dan media pembelajaran yang tepat. Oleh karena itu, pada penelitian ini, penulis ingin meneliti apakah miskonsepsi siswa pada sub pokok bahasan Geometri Molekul dapat diminimalisir dengan penerapan model pembelajaran Inkuiri Terbimbing menggunakan media pembelajaran molymod.

Penelitian ini bertujuan untuk mengetahui apakah penerapan model pembelajaran Inkuiri Terbimbing dengan menggunakan media molymod dapat mengurangi miskonsepsi siswa pada sub pokok bahasan Geometri Molekul kelas X MIPA 7 SMA Negeri 1 Samarinda.

\section{METODE PENELITIAN}

Metode penelitian yang digunakan adalah eksperimen semu (quasi experiment) dengan desain penelitian one group pretest-posttest design. Teknik pengumpulan data yang digunakan berupa tes diagnostik berupa soal pilihan ganda dengan lembar jawaban yang dilengkapi dengan kriteria Certainty of Response Index (CRI), yang digunakan untuk mengetahui kelompok pemahaman siswa. Populasi pada penelitian ini adalah siswa kelas X MIPA SMAN 1 Samarinda dari 7 kelas yang berjumlah 256 siswa. Sampel pada penelitian ini adalah siswa kelas X MIPA 7 yang berjumlah 32 orang. Teknik pengambilan sampel adalah purposive sampling, pengambilan sampel pada penelitian ini didasarkan pada hasil belajar siswa dengan kemampuan sedang yang dapat mewakili keseluruhan kemampuan siswa dalam populasi. Pertimbangan ini didasarkan pada hasil belajar siswa pada materi kimia bab sebelumnya yang bersumber dari dokumentasi nilai oleh guru kimia mereka. Teknik pengumpulan data yang digunakan berupa tes diagnostik berupa soal pilihan ganda dengan lembar jawaban yang dilengkapi dengan kriteria Certainty of Response Index (CRI) yang digunakan untuk mengetahui kelompok pemahaman siswa disertai dengan observasi atau pengamatan terhadap kegiatan pembelajaran oleh guru.

Penelitian ini dilaksanakan dalam enam kali pertemuan. Pada pertemuan pertama hingga pertemuan ketiga siswa dijelaskan mengenai materi ikatan kimia dengan model pembelajaran langsung. Pada pertemuan keempat, siswa diberikan tes diagnostik 1 dengan jumlah soal 15 soal pilihan ganda, dengan tingkat keyakinan berdasarkan pada indeks CRI. Tes diagnostik 1 yang diberikan bertujuan untuk mengetahui sejauh mana pemahaman siswa setelah materi ikatan kimia diberikan selama 3 pertemuan sebelumnya. Selanjutnya, melalui tes diagnostik 1 ini dapat ditentukan pula miskonsepsi yang dialami oleh siswa. 
Pada pertemuan kelima, siswa diberikan kembali materi sama seperti tahap pertama namun dikhususkan pada sub pokok bahasan geometri molekul, karena tujuan dari penelitian ini adalah untuk mengetahui pergeseran miskonsepsi siswa pada sub pokok bahasan geometri molekul, oleh karena itu pembelajaran ulang dengan menggunakan model pembelajaran inkuiri terbimbing hanya difokuskan pada pokok bahasan yang diteliti saja. Kemudian pada pertemuan keenam siswa diberikan tes diagnostik 2 sebagai pengukur pemahaman dan pergeseran miskonsepsi siswa setelah diberikan pembelajaran dengan model pembelajaran inkuiri terbimbing.

Observasi pada penelitian ini dilakukan observasi secara langsung terhadap kegiatan guru selama pembelajaran dengan menggunakan model inkuiri terbimbing menggunakan lembar observasi yang berisi skala penilaian yang bertujuan untuk mengetahui apakah kegiatan pembelajaran dengan model inkuiri terbimbing dilakukan atau tidak. Teknik tes pada penelitian kali ini menggunakan tes tertulis dengan bentuk soal pilihan ganda. Soal tes digunakan untuk mengetahui derajat miskonsepsi siswa diukur dari tingkat keyakinannya. Tes yang diberikan meliputi tes diagnostik 1 dan tes diagnostik 2. Soal-soal pada tes diagnostik mengukur pencapaian siswa setelah melakukan proses pembelajaran. Pertanyaan yang disusun berupa soal-soal pilihan ganda dengan jenis pertanyaan terstruktur sebanyak 15 soal. Fokus dalam penelitian ini adalah butir soal nomor 7-15, karena butir soal tersebut memuat indikator dari pembelajaran pada sub pokok bahasan geometri molekul.

Analisis data miskonsepsi dilakukan sesuai dengan analisis CRI yang dilakukan oleh Saleem Hasan. Saleem Hasan (1999) mengidentifikasi terjadinya miskonsepsi, sekaligus dapat membedakannya dengan tidak tahu konsep, dengan mengembangkan suatu metode identifikasi yang dikenal dengan istilah CRI (Certainty of Response Index). CRI yang rendah menandakan ketidakyakinan konsep pada diri responden dalam menjawab suatu pertanyaan, sebaliknya CRI yang tinggi mencerminkan keyakinan dan kepastian konsep yang tinggi pada diri responden. CRI dikembangkan dengan skala enam (0-5) seperti pada Tabel 1 berikut ini.
Tabel 1

Kriteria CRI

\begin{tabular}{|c|l|}
\hline CRI & \multicolumn{1}{|c|}{ Kriteria } \\
\hline 0 & $\begin{array}{l}\text { Menjawab dengan 100\% menebak (Totally } \\
\text { Guess Answer) }\end{array}$ \\
\hline 1 & $\begin{array}{l}\text { Menjawab dengan unsur tebakan 75-99\% } \\
\text { (Almost a Guess) }\end{array}$ \\
\hline 2 & $\begin{array}{l}\text { Menjawab dengan unsur tebakan 50-74\% } \\
\text { (Not Sure) }\end{array}$ \\
\hline 3 & $\begin{array}{l}\text { Menjawab dengan unsur tebakan 25-49\% } \\
\text { (Sure) }\end{array}$ \\
\hline 4 & $\begin{array}{l}\text { Menjawab dengan unsur tebakan 1-24\% } \\
\text { (Almost Certain) }\end{array}$ \\
\hline 5 & $\begin{array}{l}\text { Menjawab dengan tidak ada unsur tebakan } \\
\text { (Certain) }\end{array}$ \\
\hline
\end{tabular}

Dengan menggunakan CRI maka dapat terungkap kelompok siswa yang mengalami miskonsepsi, tidak tahu konsep, dan paham konsep seperti pada Tabel 2 berikut.

\section{Tabel 2}

Kelompok CRI

\begin{tabular}{|l|l|l|}
\hline \multicolumn{1}{|c|}{$\begin{array}{c}\text { Kriteria } \\
\text { Jawaban }\end{array}$} & $\begin{array}{l}\text { CRI Rendah } \\
(\text { CRI }<2,5)\end{array}$ & \multicolumn{1}{c|}{$\begin{array}{c}\text { CRI Tinggi } \\
(\text { CRI }>2,5)\end{array}$} \\
\hline $\begin{array}{l}\text { Jawaban } \\
\text { Benar }\end{array}$ & $\begin{array}{l}\text { Tidak } \\
\text { Memahami } \\
\text { Konsep }\end{array}$ & $\begin{array}{l}\text { Memahami } \\
\text { Konsep }\end{array}$ \\
\hline $\begin{array}{l}\text { Jawaban } \\
\text { Salah }\end{array}$ & $\begin{array}{l}\text { Tidak } \\
\text { Memahami } \\
\text { Konsep }\end{array}$ & Miskonsepsi \\
\hline
\end{tabular}

Persentase perhitungan kelompok berdasarkan kategori kriteria CRI, dengan rumus:

$$
\mathrm{P}=\frac{\mathrm{f}}{\mathrm{N}} \times 100 \%
$$

Dimana $: \mathrm{P}=\%$ kelompok

$\mathrm{F}=$ jumlah siswa tiap kelompok

$\mathrm{N}=$ jumlah seluruh subjek penelitian (sampel)

\section{HASIL DAN PEMBAHASAN}

Penelitian ini memfokuskan pengurangan miskonsepsi siswa pada sub pokok bahasan Geometri Molekul. Butir soal nomor 1-15 yang digunakan pada tes diagnostik 1 dan tes diagnostik 2 merupakan butir soal yang mewakili materi ikatan kimia secara keseluruhan, namun butir soal 1-6 bukanlah butir soal yang mengacu pada indikator pembelajaran pada sub pokok bahasan Geometri Molekul, sehingga untuk hasil penelitian dan pembahasan soal akan mengacu pada soal nomor 715 saja.

\section{Hasil Tes Diagnostik 1}

Tes diagnostik 1 dilakukan setelah siswa menerima pembelajaran langsung. Tes diagnostik ini ditujukan untuk mengetahui pencapaian siswa 
setelah diberikan pembelajaran langsung pada materi ikatan kimia. Selain itu, pada tes diagnostik ini dapat diketahui persentase siswa yang mengalami miskonsepsi, memahami konsep dan yang tidak memahami konsep pada sub pokok bahasan Geometri Molekul. Persentase setiap kelompok siswa pada tes diagnostik 1 dapat diamati pada Tabel 3.

Tabel 3

Hasil Tes Diagnostik 1

\begin{tabular}{|c|c|c|c|}
\hline \multirow{2}{*}{$\begin{array}{c}\text { Nomor } \\
\text { Soal }\end{array}$} & \multicolumn{3}{|c|}{ Kelompok Siswa } \\
\cline { 2 - 4 } & $\begin{array}{c}\text { Memahami } \\
\text { Konsep } \\
\text { (MK) }\end{array}$ & $\begin{array}{c}\text { Miskonsepsi } \\
\text { (MS) }\end{array}$ & $\begin{array}{c}\text { Tidak } \\
\text { Memahami } \\
\text { Konsep } \\
\text { (TMK) }\end{array}$ \\
\hline 7 & $43,75 \%$ & $31,25 \%$ & $25 \%$ \\
\hline 8 & $6,25 \%$ & $56,25 \%$ & $37,50 \%$ \\
\hline 9 & $15,63 \%$ & $75 \%$ & $9,38 \%$ \\
\hline 10 & $18,75 \%$ & $50 \%$ & $31,25 \%$ \\
\hline 11 & $21,88 \%$ & $40,63 \%$ & $37,50 \%$ \\
\hline 12 & $15,63 \%$ & $56,25 \%$ & $28,13 \%$ \\
\hline 13 & $34,38 \%$ & $43,75 \%$ & $21,88 \%$ \\
\hline 14 & $6,25 \%$ & $56,25 \%$ & $37,50 \%$ \\
\hline 15 & $15,63 \%$ & $50 \%$ & $34,38 \%$ \\
\hline
\end{tabular}

\section{Hasil Tes Diagnostik 2}

Tes diagnostik 2 dilakukan setelah siswa menerima pembelajaran treatment dengan model pembelajaran Inkuiri Terbimbing dan media pembelajaran molymod pada pokok bahasan geometri molekul. Pada tes diagnostik ini, dapat diketahui apakah pemberian pembelajaran treatment dengan Inkuiri Terbimbing dapat mengurangi miskonsepsi siswa. Persentase kelompok siswa pada tes diagnostik 2 dapat dilihat pada tabel 4 .

Tabel 4

Hasil Tes Diagnostik 2

\begin{tabular}{|c|c|c|c|}
\hline \multirow{2}{*}{$\begin{array}{c}\text { Nomor } \\
\text { Soal }\end{array}$} & \multicolumn{3}{|c|}{ Kelompok Siswa } \\
\cline { 2 - 4 } & $\begin{array}{c}\text { Memahami } \\
\text { Konsep } \\
\text { (MK) }\end{array}$ & $\begin{array}{c}\text { Miskonsepsi } \\
\text { (MS) }\end{array}$ & $\begin{array}{c}\text { Tidak } \\
\text { Memahami } \\
\text { Konsep } \\
\text { (TMK) }\end{array}$ \\
\hline 7 & $43,75 \%$ & $31,25 \%$ & $25 \%$ \\
\hline 8 & $6,25 \%$ & $56,25 \%$ & $37,50 \%$ \\
\hline 9 & $15,63 \%$ & $75 \%$ & $9,38 \%$ \\
\hline 10 & $18,75 \%$ & $50 \%$ & $31,25 \%$ \\
\hline 11 & $21,88 \%$ & $40,63 \%$ & $37,50 \%$ \\
\hline 12 & $15,63 \%$ & $56,25 \%$ & $28,13 \%$ \\
\hline 13 & $34,38 \%$ & $43,75 \%$ & $21,88 \%$ \\
\hline 14 & $6,25 \%$ & $56,25 \%$ & $37,50 \%$ \\
\hline 15 & $15,63 \%$ & $50 \%$ & $34,38 \%$ \\
\hline
\end{tabular}

\section{Perbandingan Miskonsepsi}

Berdasarkan hasil pada tes diagnostik 1 dan tes diagnostik 2 dapat dianalisis pengurangan miskonsepsi siswa dengan membandingkan persentase kelompok siswa yang mengalami miskonsepsi pada kedua tes diagnostik tersebut. Penurunan miskonsepsi siswa dapat diamati secara lengkap pada tabel 5 .

Tabel 5

Penurunan miskonsepsi siswa

\begin{tabular}{|c|c|}
\hline $\begin{array}{c}\text { Nomor } \\
\text { Soal }\end{array}$ & Penurunan Miskonsepsi Siswa \\
\hline 7 & $31,25 \%$ \\
\hline 8 & $25 \%$ \\
\hline 9 & $53,13 \%$ \\
\hline 10 & $46,88 \%$ \\
\hline 11 & $37,50 \%$ \\
\hline 12 & $40,63 \%$ \\
\hline 13 & $31,25 \%$ \\
\hline 14 & $28,13 \%$ \\
\hline 15 & $31,25 \%$ \\
\hline
\end{tabular}

Dalam proses pembelajaran langsung, model pembelajaran langsung lebih didominasi oleh guru, hal ini mencerminkan bahwa pembelajaran langsung bersifat teacher Centered. Berbeda halnya dengan pembelajaran Inkuiri Terbimbing, model pembelajaran ini memberikan kesempatan pada siswa untuk aktif membangun pengetahuannya sendiri melalui proses pengamatan inkuiri. Adapun Sintak yang dilakukan pada pembelajaran Inkuiri Terbimbing yaitu:

1. Menyajikan pertanyaan atau masalah

2. Membuat hipotesis

3. Merancang percobaan

4. Mengumpulkan data (melakukan percobaan/experimenting atau cara pemecahan masalah yang lain)

5. Menganalisis data

6. Membuat kesimpulan

Sebagai data utama dari penelitian ini, terdapat tes tertulis yang digunakan sebagai data untuk melihat penurunan miskonsepsi siswa setelah menerima pembelajaran treatment. Dari hasil analisis terdapat miskonsepsi yang dialami oleh siswa, dapat diuraikan profil miskonsepsi siswa pada gambar 1. 


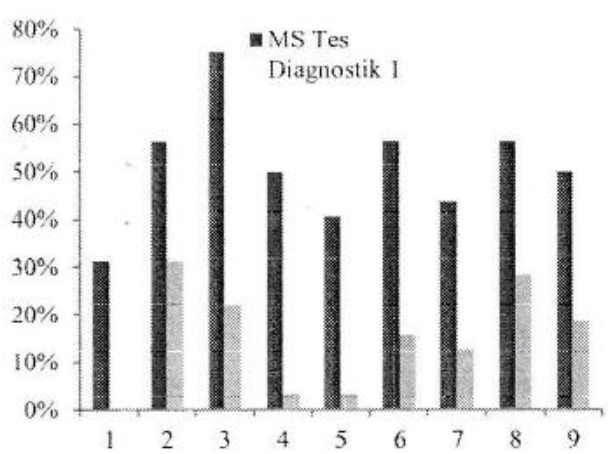

Berdasarkan gambar 1, setelah menerima pembelajaran menggunakan treatment model pembelajaran Inkuiri Terbimbing dengan berbantuan media pembelajaran molymod, miskonsepsi siswa pada tes diagnostik satu berkurang secara signifikan dibandingkan dengan miskonsepsi siswa setelah tes diagnostik 2 .

Pada butir soal nomor 7 yang mewakili indikator menentukan bentuk molekul berdasarkan teori VSEPR dan teori Domain Elektron. Tes diagnostik 1 menunjukkan kelompok siswa yang mengalami miskonsepsi mencapai $31,25 \%$, namun pada tes diagnostik 2 tidak ada lagi siswa yang mengalami miskonsepsi. Hal ini menandakan bahwa sebesar 31,25\% miskonsepsi siswa berkurang setelah menerima pembelajaran treatment. Pada butir soal ini, siswa diminta untuk menentukan bentuk molekul suatu senyawa dengan jumlah pasangan elektron bebas (PEB) dan jumlah pasangan elektron terikat (PEI) yang telah diketahui.

Pada butir soal nomor 8 yang mewakili indikator soal menentukan bentuk molekul berdasarkan teori VSEPR dan teori Domain Elektron, siswa diminta untuk menentukan bentuk molekul senyawa berdasarkan konfigurasi elektron yang telah disajikan dalam soal. Pada tes diagnostik 1, tingkat siswa yang mengalami miskonsepsi mencapai 56,25\%, berbeda halnya dengan pembelajaran Inkuiri Terbimbing. Penekanan proses pada pembelajaran Inkuiri Terbimbing terbukti mampu menurunkan miskonsepsi siswa. Hal tersebut terbukti pada tes diagnostik 2, persentase miskonsepsi turun menjadi 31,25\%. Hal ini menandakan bahwa sebesar $25 \%$ miskonsepsi siswa berkurang.

Pada butir soal nomor 9 yang mewakili indikator menentukan bentuk molekul berdasarkan teori VSEPR dan teori Domain Elektron, siswa diminta untuk menentukan jumlah pasangan elektron Terikat pada molekul trigonal bipiramida. Pada tes diagnostik 1 di mana kelompok siswa yang mengalami miskonsepsi mencapai $75 \%$. Pada tes diagnostik 2 miskonsepsi siswa berkurang menjadi $21,88 \%$. Hal ini menandakan bahwa sebesar 53,13\% miskonsepsi siswa berkurang setelah menerima pembelajaran treatment.

Pada butir soal nomor 10 yang mewakili indikator menggambarkan rumus Lewis untuk molekul poliatomik dan meramalkan bentuk molekulnya, siswa diminta untuk menentukan bentuk molekul dan sifat kepolaran suatu senyawa berdasarkan nomor atomnya. Hasil tes diagnostik 1 menunjukkan kelompok siswa yang mengalami miskonsepsi mencapai $40,625 \%$. Namun pada tes diagnostik 2 miskonsepsi siswa berkurang menjadi $3,125 \%$. Hal ini menandakan bahwa sebesar 37,50\% miskonsepsi siswa berkurang.

Pada butir soal nomor 12 yang mewakili indikator menentukan bentuk molekul yang berdasarkan teori VSEPR dan teori Domain Elektron, siswa diminta untuk menentukan bentuk geometri molekul dari suatu senyawa yang diketahui. Pada tes diagnostik 1, kelompok siswa yang mengalami miskonsepsi mencapai 56,25\%, namun pada tes diagnostik 2 miskonsepsi siswa berkurang menjadi $15,625 \%$. Hal ini menandakan bahwa sebesar $40,63 \%$ miskonsepsi siswa berkurang.

Pada butir soal nomor 13 yang mewakili indikator menggambarkan rumus Lewis untuk molekul poliatomik dan meramalkan bentuk molekulnya, siswa diminta untuk menentukan jumlah pasangan elektron ikatan dan pasangan elektron bebas dari suatu senyawa yang diketahui bentuk molekulnya. Pada tes diagnostik 1 yang menunjukkan kelompok siswa yang mengalami miskonsepsi mencapai $43,75 \%$ namun pada tes diagnostik 2 miskonsepsi siswa berkurang menjadi $12,5 \%$. Hal ini menandakan bahwa sebesar $31,25 \%$ miskonsepsi siswa berkurang.

Pada butir soal nomor 14 yang mewakili indikator menentukan bentuk molekul berdasarkan teori VSEPR dan teori Domain Elektron, siswa diminta untuk menentukan bentuk molekul dari suatu ion. Pada tes diagnostik 1, di mana kelompok siswa yang mengalami miskonsepsi mencapai $56,25 \%$, namun pada tes diagnostik 2 miskonsepsi siswa berkurang menjadi $28,125 \%$. Hal ini menandakan bahwa sebesar $28,13 \%$ miskonsepsi siswa berkurang. 
Pada butir soal nomor 15 yang mewakili indikator menentukan bentuk molekul berdasarkan teori VSEPR dan teori Domain Elektron, siswa diminta untuk menentukan sebab mengapa sudut ikatan yang terbentuk pada molekul air lebih kecil. Pada tes diagnostik 1 yang menunjukkan kelompok siswa yang mengalami miskonsepsi mencapai $50 \%$, namun pada tes diagnostik 2 miskonsepsi siswa berkurang menjadi $18,75 \%$. Hal ini menandakan bahwa sebesar $31,25 \%$ miskonsepsi siswa berkurang.

Miskonsepsi dapat berkurang karena pemahaman siswa telah diperbaiki pada pembelajaran treatment dengan memberikan media molymod dengan mengkonstruksi pemahaman konsep yang lebih baik tentang geometri molekul. Kecenderungan yang terjadi pada tes diagnostik 1 menunjukkan bahwa pemahaman konsep siswa masih kurang karena siswa hanya menerima pembelajaran langsung pada satu pokok materi yang menuntut pemahaman mendalam. Oleh karena itu, pembelajaran pada sub pokok bahasan geometri molekul dengan menggunakan molymod memberikan hasil yang lebih baik, hal ini dibuktikan dengan berkurangnya persentase kelompok miskonsepsi siswa pada tes diagnostik 2 .

Pengurangan miskonsepsi terkecil terjadi pada butir soal nomor 8 di mana sebesar $25 \%$ miskonsepsi siswa berkurang dan pengurangan miskonsepsi terbesar terjadi pada butir soal nomor 9 di mana sebesar 53,13\% miskonsepsi siswa berkurang. Hal ini terjadi karena butir soal nomor 8 menuntut pemahaman lebih dalam dimana siswa diminta untuk menentukan geometri molekul berdasarkan konfigurasi elektron dan di dalam soal tidak disebutkan rumus molekul serta jumlah ligan dan siapa yang berperan sebagai atom pusat. Hal ini bersesuaian dengan media molymod yang digunakan dalam pembelajaran pada hakekatnya hanya membantu siswa menggambarkan secara riil bentuk tiga dimensi suatu molekul tapi siswa tetap harus menentukan sendiri molekul yang terbentuk serta notasi molekulnya. Sementara itu, butir soal nomor 9 adalah butir soal yang mengalami pergeseran miskonsepsi terbesar. Hal ini terjadi karena pada butir soal nomor 9 siswa diminta untuk menentukan jumlah pasangan elektron yang berikatan dalam suatu bentuk molekul. Penggunaan molymod dalam pembelajaran terbukti sangat membantu siswa dalam memecahkan persoalan seperti ini.
Belajar melalui pengamatan diyakini akan lebih bermakna daripada hanya sekedar mendengar dan membayangkan. Media pembelajaran dapat membantu siswa memproyeksikan secara nyata apa yang selama ini hanya ada dalam bayangan mereka. Adanya interaksi positif antara media pembelajaran dan siswa pada akhirnya akan mampu mempercepat proses pemahaman siswa terhadap isi pembelajaran. Itulah sebabnya komponen itu lebih menaruh perhatian pada kajian mengenai kegiatan belajar pada yang dilakukan siswa dan bagaimana peranan media untuk merangsang kegiatan kegiatan belajar tersebut (Degeng, 1989) (dalam Made Wena, 2008). Molymod terbukti dapat meningkatkan pemahaman siswa tentang konsep bentuk molekul (Gia Mustika, 2012). Disamping terhindar dari kekeliruan dalam membayangkan, pemahaman konsep siswa juga akan melekat lebih permanen. Kelebihan-kelebihan inilah yang menyebabkan penggunaan model pembelajaran Inkuiri Terbimbing dengan media pembelajaran molymod mampu mengurangi miskonsepsi siswa pada sub pokok bahasan Geometri Molekul.

\section{PENUTUP}

\section{Simpulan}

Model pembelajaran inkuiri terbimbing berbantuan media pembelajaran molymod efektif untuk mengurangi miskonsepsi siswa pada sub pokok bahasan Geometri Molekul di kelas X MIPA 7 SMA Negeri 1 Samarinda.

\section{Saran}

Perlu adanya penerapan pembelajaran Inkuiri Terbimbing dengan menggunakan media pembelajaran visual yang lain agar pembelajaran bisa menjadi lebih inovatif lagi dan dapat memberikan hasil yang lebih baik.

\section{UCAPAN TERIMAKASIH}

Kepala Sekolah, dewan guru, Bu Indah Rokhani serta staf tata usaha serta siswa-siswa SMA Negeri 1 Samarinda yang telah memberikan izin kepada penulis untuk melaksanakan penelitian.

\section{DAFTAR PUSTAKA}

Anam, K. 2015. Pembelajaran Berbasis Inkuiri. Pustaka Pelajar: Yogyakarta.

Janawi. 2013. Metodologi dan Pendekatan Pembelajaran. Penerbit Ombak (Anggota IKAPI): Yogyakarta

Kasmadi, dan Nia. 2013. Panduan Modern Penelitian Kuantitatif. Bandung: Alfabeta 
Muna, I.A. 2015. "Identifikasi Miskonsepsi Mahasiswa PGMI pada Konsep Hukum Newton Menggunakan Certainty of Response Index (CRI)". Cendekia Vol. I3 No. 2. Ponorogo : STAIN.

Pramudjono. 2010. Statistika Dasar. Samarinda: Puri Kencana Mandiri

Sendy, Z.W. dan Budi J. "Penerapan Model Pembelajaran Inkuiri Terbimbing (Guided Inquiry) untuk Mengurangi Miskonsepsi Siswa Kelas X SMAN 2 Ponorogo pada Pokok Bahasan Perpindahan Panas". Jurnal Inolasi Pendidikan Fisika (JIPF). 2011. Vol. 03 No. 03 Tahun 10 14. 6-10 1SSN: 2302-4496. <http://ejournal.unesa.ac.id/>.

Suhana, C. 2014. Konsep Strategi Pembelajaran. Refika Aditama: Bandung

Suprihatiningrum, J. 2013. Strategi Pembelajara Teori dan Aplikasi. Ar-Ruzz Media: Jakarta.

Wena, M. 2008. Strategi Pembelajaran Inovatif Kontemporer. Bumi Aksara: Jakarta.

Yaumi, M. 2013. Prinsip-Prinsip Desain Pembelajaran. Kencana Prenada Media Group: Jakarta. 